\title{
QUEEN'S
UNIVERSITY
BELFAST
}

\section{Forensic Geoscience: applications of geology, geomorphology and geophysics to criminal investigations}

Ruffell, A., \& McKinley, J. (2005). Forensic Geoscience: applications of geology, geomorphology and geophysics to criminal investigations. Earth-Science Reviews, 69(3-4)(3-4), 235-247.

https://doi.org/10.1016/j.earscirev.2004.08.002

\section{Published in:}

Earth-Science Reviews

Queen's University Belfast - Research Portal:

Link to publication record in Queen's University Belfast Research Portal

\section{General rights}

Copyright for the publications made accessible via the Queen's University Belfast Research Portal is retained by the author(s) and / or other copyright owners and it is a condition of accessing these publications that users recognise and abide by the legal requirements associated with these rights.

Take down policy

The Research Portal is Queen's institutional repository that provides access to Queen's research output. Every effort has been made to ensure that content in the Research Portal does not infringe any person's rights, or applicable UK laws. If you discover content in the Research Portal that you believe breaches copyright or violates any law, please contact openaccess@qub.ac.uk. 


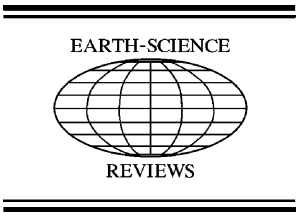

www.elsevier.com/locate/earscirev

\title{
Forensic geoscience: applications of geology, geomorphology and geophysics to criminal investigations
}

\author{
Alastair Ruffell*, Jennifer McKinley \\ School of Geography, Queen's University, Belfast, BT7 1NN, N. Ireland
}

Received 12 January 2004; accepted 24 August 2004

\begin{abstract}
One hundred years ago Georg Popp became the first scientist to present in court a case where the geological makeup of soils was used to secure a criminal conviction. Subsequently there have been significant advances in the theory and practice of forensic geoscience: many of them subsequent to the seminal publication of "Forensic Geology" by Murray and Tedrow [Murray, R., Tedrow, J.C.F. 1975 (republished 1986). Forensic Geology: Earth Sciences and Criminal Investigation. Rutgers University Press, New York, 240 pp.]. Our review places historical development in the modern context of how the allied disciplines of geology (mineralogy, sedimentology, microscopy), geophysics, soil science, microbiology, anthropology and geomorphology have been used as tool to aid forensic (domestic, serious, terrorist and international) crime investigations. The latter half of this paper uses the concept of scales of investigation, from large-scale landforms through to microscopic particles as a method of categorising the large number of geoscience applications to criminal investigation. Forensic geoscience has traditionally used established non-forensic techniques: 100 years after Popp's seminal work, research into forensic geoscience is beginning to lead, as opposed to follow other scientific disciplines.
\end{abstract}

(C) 2004 Elsevier B.V. All rights reserved.

Keywords: Forensic; Scene of crime; Geophysics; Remote sensing; Petrography; Geochemistry

\section{Introduction}

Cursory examination of the World Wide Web, recent scientific meetings worldwide or journals such as Forensic Science International or the Journal of Forensic Science demonstrate the recent (arbitrarily, from 1999 to 2004) and growing interest in forensic

* Corresponding author. Fax: +44 1232321280 .

E-mail address: a.ruffell@qub.ac.uk (A. Ruffell). geoscience. Many of the two hundred or more university courses on forensic science (Chamakura, 2001) include a substantial element on geoscience. A cynic may consider this to be a product of the current popularity of television programmes such as Crime Scene Investigators (Columbia Broadcasting Service, 2003) and Silent Witness (British Broadcasting Centre, 2003) or of similar books by Patricia Cornwell (Nielsen, 2003) and Sarah Andrews (e.g. Andrews, 2002). However, as we shall demonstrate in this review, the current interest in geoscience and forensic 
investigations can be better understood in terms of the episodic evolution of scientific applications to domestic, terrorist and international criminal prosecution. In addition, novelists such as Conan-Doyle, Cornwell and Andrews have all made significant contributions to the science, as well as the popularity of the stories behind the investigations. The application of geoscientific techniques to forensic investigations has followed methodological and personality-driven routes. Previous to the late 1800 s there are anecdotal accounts of what we would consider forensic geoscience (e.g. tracking the accused criminal by footprints) in China and India. Through the late 1800 s to mid 20th Century forensic geology was dominated by individual personalities who advocated specific theories or techniques, for example, Locard's 1910 Exchange Principle (see Chisum and Turvey, 2000) and the establishment of institutions dedicated to the scientific analysis of crime. Two early examples include the School of Forensic Science and Criminology at the University of Lausanne, created by Rodolphe Reiss in 1909 (http://www2.unil.ch/ips/ docs/nava1.html, accessed 26/6/04) and Locard's own police laboratory in Lyons (1910). From the 1930s to 1970 s forensic geology and allied disciplines (soil science, glass composition, botany) was dominated by governmental institutions, especially the Federal Bureau of Investigation (USA) and Central Research Establishment, or Aldermaston (UK). A major change occurred in 1975 with the publication of Raymond Murray and John Tedrow's book on Forensic Geology; a compendium of investigative techniques that drew on both the authors' and other research, revised in 1986. Since the re-writing of this text in 1991 (Murray and Tedrow, 1991, also cited by many authors [e.g. Croft and Pye, 2004 and Amazon-www.amazon.co.uk as 1992) there have been a wide range of geoscience applications in forensic investigations: the historical background to these advances and their recent application is reviewed in this article. Major advances in forensic geoscience have occurred in the past with the arrival of new theories or technical methods. It is possible that this application of geoscience is currently in one such period of advance: an overview of where we stand 100 years after Georg Popp's work on the murder of Eva Disch (described below with references) is thus, we hope, timely. Furthermore, this work will use
Murray and Tedrow (1991), Crelling (1998), recent scientific articles and the abstracts of meetings, most especially the INTERPOL Soil Science Symposium in Lyons, France (INTERPOL, 2001) and Pye and Croft's Geological Society of London meeting on Forensic Geoscience (March 2003) to set the historical scene. For a review of recent work, a selected number of websites and abstracts from scientific meetings will be reviewed. Much of the information referred to is not published in standard journals. Preference in citation has been give to journal articles, websites and published conference proceedings, in order to aid the reader. In this article we aim to save the reader the frustration we have had, when an expert in the field says 'oh that fact has been known about for years', only to discover the work in a very limited distribution conference proceedings. In addition, many forensic scientists are unaware of how the geologist, geophysicist, palaeontologist or geographer can assist them, with most geoscience being hidden in amongst 'trace evidence' or worse still, ignored altogether (Holt, 2004), for which we as Earth scientists can only be to blame for not communicating well enough!

\section{Scope of the review}

In this review, 'forensic' (Chambers English Dictionary, 2003) pertains to the application of science to legal investigation. Geology is the study of Earth materials and in North America encompasses geomorphology and oceanography. Hence the preferred term of this article, 'geoscience', the study of all Earth surface materials. There are separate areas of study that overlap with forensic geoscience. In archaeology, gaining evidence of a crime becomes difficult through lack of accurate dating but more fundamentally because of the moral and legal code of the civilisation under study. For example, genocide is definitely a crime: however, in ancient Greece, or Mesopotamia, or in the Stone Age, or among Neanderthal culture, how can we impose a modern moral when we have no context in which to place events? Many geomorphological forensic investigations involve water, as litigious problems of supply, pollution, flooding, subsidence and erosion. Legal enquiries into the operations of the extractive industry (especially rock, 
minerals and sand) often employ geomorphologists who assess changes to the landscape, problems of erosion and excessive deposition. Some military activity is perhaps the most contentious 'forensic' type examination. Here, exactly the same examination of materials, linking of suspects to activities and locations occurs, but not often with civil or international legal prosecution in mind. An excellent example is the exploration for buried landmines. When undertaken by one sovereign authority in conflict with another, this activity would be considered surveillance and counter-insurgency during warfare. Landmine detection for humanitarian aid or counter-terrorism is more akin to forensic investigation. The common feature of both activities is the method of detection, rather than the military, humanitarian or criminal outcome. Because many of the techniques used by military organisations are the same as civilian, and because of the lack of citeable material, military forensic investigations will not be discussed at length in this article. However, international law, terrorism, genocide, buried ordnance and landmines and remote sensing will be considered. Forensic applications include detecting the breaking of environmental law (pollution, mineral and oil extraction); monitoring illegal extraction and movement of gems, drugs, minerals and the settling of border disputes using Geographic Information Systems (amongst others). The above problems in the definition of forensic geoscience can be alleviated in this review by basing descriptions on methodology rather than application. Most published uses of forensic geoscience are domestic and national crime, which will be used as case studies: should archaeological, military or international applications be available, these will be used if appropriate.

\section{Historical overview}

In 1887 Sir Arthur Conan Doyle published 'A Study in Scarlet' in Beeton's Christmas Annual of London. Conan Doyle stories with a forensic geology base that followed included 'The Five Orange Pips' (1891) and 'Through the Magic Door' (1907). Conan-Doyle was well aware of geology, mineralogy and soils, being educated in these aspects of the natural sciences whilst at Cambridge Univer- sity in England. His writings often include references to the stones of buildings and bridges that are important to the story. The classic role of the forensic geologist, the linking of soil on clothes to that of a scene of crime or activity is commonly used. That a pioneer of forensic geoscience is the fictitious Sherlock Holmes is often played - down by practioners of the science, in case they should suffer ridicule. The only problem with the geological, geomorphological and botanical references in Arthur Conan Doyle's books are the status of the theories: they are all untested by court of law or peer review publication. Otherwise, the principle of airing possible scientific technique through the popular novel is common in science fiction and thus when we discuss principles, should be included here. The passage of time and Conan Doyle's appearance in court as a witness for the defence in 1906 (Murray and Tedrow, 1975) vindicates his inclusion as a founder of forensic geoscience. In terms of the development of the science of forensic geology and geoscience outside of the novel, John Crelling (Crelling, 1998) gives a clear and comprehensive account. He provides a timeline that is utilised here.

\subsection{Hans Gross (1847-1915)}

Murray (2004) and Crelling (1998) both suggest that Gross is the best-documented founder of scientific criminal investigation. His 'Handbuch fur Untersuchungsrichter' ('Handbook for Examining Magistrates') in 1893 included discussions of forensic medicine, toxicology, serology, and ballistics, as well as forensic geology. This text included the use of microscope petrography in the study of materials such as soil recovered from shoes in order to link suspects to scenes of crime or routes. Murray (2004) suggests that the widespread legal and scientific knowledge of both Arthur Conan Doyle's fictitious Sherlock Holmes and Georg Popp's handbook meant that it was only a matter of time until someone tested their general theories and recommendations in an actual criminal case.

\subsection{Georg Popp (1867-1928)}

In 1904 Popp (the owner of a laboratory in Frankfurt, Germany) used geological evidence in a 
criminal case for the first time, as Raymond Murray (Murray and Tedrow, 1975) states:

"In October 1904, a forensic scientist in Frankfurt, Germany named Georg Popp was asked to examine the evidence in a murder case where a seamstress named Eva Disch had been strangled in a bean field with her own scarf. A filthy handkerchief had been left at the scene and the nasal mucus on the handkerchief contained bits of coal, particles of snuff, and, most interesting, grains of minerals, particularly the mineral hornblende. A suspect by the name of Karl Laubach was known to work in a coal-burning gasworks and part-time in a local gravel pit. Popp found coal, snuff and mineral grains, particularly the mineral hornblende, under the suspect's fingernails."

Furthermore, soil from the suspect's trousers matched the location where the deceased body was found as well as the route from the scene to his house. The suspect admitted the crime, making Popp famous as the "Microscope Detective". In 1908 Popp firmly established forensic geology with the Margarethe Filbert case. Murray (Murray and Tedrow, 1975) once again provides us with the main details. In the spring of 1908 Margarethe Filbert was murdered near Rockenhausen in Bavaria and Popp was asked to aid the investigation. Popp matched a suspect to the victim's home, the scene of the crime and the route he walked between the two, challenging the alibi and aiding a conviction. This was achieved through the careful examination of trace evidence and by identification of the unique mineralogy, rock and soil types along the route. Most especially, Popp used a combination of mineralogy (two types of quartz), rock (white porphyry), soil (red clay) and other materials (green goose droppings) in his evidence. As we shall see such a conjunctive approach is still one the most powerful available to the early $21 \mathrm{st}$ Century Forensic Geoscientist, 100 years after Popp aided the investigation.

\subsection{Edmond Locard (1877-1966)}

Although not specifically working on geological or similar materials, Locard's reading of the Adventures of Sherlock Holmes and parts of Gross's book were possibly part of his thinking in developing one of the fundamental theories of forensic science, Locard's
Exchange Principle "Whenever two objects come into contact, there is always a transfer of material. The methods of detection may not be sensitive enough to demonstrate this, or the decay rate may be so rapid that all evidence of transfer has vanished after a given time. Nonetheless, the transfer has taken place" (Murray and Tedrow, 1991, p. 7).

\subsection{Edward Oscar Heinrich, 1881-1953}

Crelling (1998) describes Heinrich as "The wizard of Berkeley", a 'colourful' character who extended geological, petrographic investigative techniques to sand, soil, paints and pigments. His most famous case was the linking of a suspect and his knife to a scene of crime (the murdered body of previously kidnapped Father Patrick Heslin) via the common beach sand found on and at both.

\subsection{Government agencies-20th century}

Through the first half of the 20th century, the governments and educational establishments of Switzerland, France, Germany, the United Kingdom and the United States of America began developing specialised investigative laboratories capable of geological type forensic science. Houck (2001) and Odell (1982) both give excellent overviews of the development of various institutions dedicated to forensic science. The creation of Professor Rodolphe Archibald Reiss's first University program in forensic science in the world (1909: http://www2.unil.ch/ips/ docs/nava1.html) and the Institute of Police Science (Lausanne, 1909) was followed by the Federal Bureau of Investigation (Washington, DC, from 1924 to 1935 when formalised following Edgar J. Hoover's directorship) and the Metropolitan Police Forensic Science Laboratory (London, UK, 1935). The Central Research Establishment (Aldermaston, UK) was set up considerably later (1966). The Federal Bureau of Investigation were using forensic geology as early as 1935 and helped solve the Matson kidnapping case in 1936 (Murray and Tedrow, 1991). The FBI used heavy mineral separations for soil characterization as early as 1939 and geology was critical in the USDEA Agent, Enrique Camarena case in 1985 (Murray and Tedrow, 1991). In this case, soil obtained from the clothing of the murdered and buried Camarena in 
Mexico was different to the proposed burial site, demonstrating removal of his body and a cover-up by the Mexican authorities.

\subsection{Walter McCrone (1916-2002)}

McCrone developed the use of chemical microscopy in order to test and challenge historical theories. Thus his work was not strictly forensic but the techniques and devices he developed have been crucial in forensic and Archaeological geoscience. Walter C. McCrone's most famous forensic type analysis was that of the Turin Shroud, which he showed never enveloped the body of Jesus (Lewis, 2002). He also produced evidence contradicting the theory that Napoleon was poisoned on St. Helena by agents of the re-established French monarchy: the arsenic levels he found in the emperor's hair were simply too low. Conversely, he showed through analysis of Beethoven's hair that the composer had suffered from lead poisoning, explaining the documented fits of depression and perhaps his deafness. McCrone's work on the Turin Shroud was based on optical microscopy but utilised radiocarbon dating and palynology in a truly conjunctive style: a radical methodology as we shall see in the following sections. In 1988, independent carbon dating demonstrated, as Dr. McCrone had, that the linen dated from a time about 13 centuries after the Crucifixion. A 1999 analysis of pollen grains taken from the shroud, however, placed its origin near Jerusalem before the eighth century. His discovery of the modern pigment titanium oxide in the supposedly Medieval Vinland Map, proved it to be a fake. He founded the non-profit making McCrone Research Institute (http://www. mcri.org/) which advises on the use of microscopes.

\subsection{Raymond Murray}

Raymond Murray co-published (with John Tedrow) in 1975 "Forensic geology; earth sciences and criminal investigation" (Rutgers University Press). The success of this book led to revised editions being published in 1986 and 1991. An updated version with new case studies proves the continuing use such a book has (Murray, 2004). The 1975 text fulfilled three important roles in the continuing development of the science. First, the history and principles were documented, much as this article has so far done. Next, case studies were provided that showed the success of well-researched forensic geology. Lastly, some principles were established for the collection, examination, evaluation of evidence, the conclusions that can be drawn for presentation in a court of law, the testing of these theories and the eventual legal finale to the process. The sequential examination procedures, drawn up by Skip Palenik (in Murray and Tedrow, 1991, their Table 9-2) remain a fundamental starting point in the forensic examination of soils, rocks and similar materials. Murray's chapter on forensic geology in Saferstein (2001) condensed and revised the 1991 work for inclusion in a book on criminalistics.

\section{Review of forensic geoscience in 2003}

This review aims to place the historical aspects (above) into the context of current practice and developments. Thus we have elected to follow a broadly scale-dependant structure, starting with the large scale of reconnaissance and exploratory geophysics, landforms, geomorphology and remote sensing, homing in on microscopic and geochemical methods. The boundary between the large (landscape) and small (trace evidence of grams to milligrams) scales is arbitrary with footwear and tyre-tread marks being good examples of features of the landscape that are more appropriately discussed among criminal investigations of small scale (less than a few centimetres) by virtue of the types of analysis undertaken. Dividing this review by scale works for most descriptions except stratigraphy, where in forensic anthropology, stratigraphy is important at a macroscale (Bass and Birkby, 1978) and in footwear-tread, layering maybe critical at the micro-scale (see Murray's (2004) description of Georg Popp).

4.1. The large scale: forensic geophysics, geomorphology and remote sensing

\subsubsection{Resistivity and electrical tomography}

The immediate subsurface of the Earth may comprise soil, rock, roadways and foundations, 'made ground' (human-dumped materials), beaches, etc. All these materials are inhertantly variable, their 
humus and water content, cation exchange capacity, bulk density, structure, and texture all affect electrical resistivity. These properties differ considerably in depth and space, sometimes over distances of one centimetre (Pozdnyakova, 2003). Resistivity is often measured over an area and a map of different soil (or other) material resistances displayed. Depth resistivity is carried out by injecting electrical currents along an array of electrodes (e.g. van Schoor, 2002) in the ground and provides a depth section of resistance (a tomograph, hence, electrical tomography). Disturbance (e.g. digging) mixes materials and thus the resistivity of subsurface materials such as soils. Areas of different electrical resistance are detectable by measuring resistivity with directly injected currents: the depth of penetration is normally tens of centimetres (France et al., 1992). Disturbed ground (such as burial sites) can be detected by changes in resistivity many years after the initial disturbance. France et al. (1992), Buck (2003) and Cheetham (2003) all provide forensic-based accounts of the uses of resistivity and other electrical-based survey techniques.

\subsubsection{Electromagnetics}

Electromagnetic (or EM surveying) refers to low frequency EM methods that induce current flow in the ground without use of electrodes, unlike the DC resistivity methods (above). EM surveys use low $(1000-10,000 \mathrm{~Hz})$ electrical frequencies that have long $(100 \mathrm{~km})$ wavelengths, making them occasionally unsuitable for detecting small targets. Nobes (1999) pioneered the careful conjunctive use of EM with ground-penetrating radar in the specific search of burial sites. Nobes (2000) documents the conjunctive use of EM surveys with ground-penetrating radar (GPR) in the case of a missing woman where radar was not as successful as many of the cases cited below. In this case, EM surveying was used in a reconnaissance manner to focus the subsequent GPR survey. EM surveys are used in similar ways by commercial companies (see for instance Davenport, 2001a,b).

\subsubsection{Ground-penetrating radar}

GPR (for short) has become the main geophysical tool of the forensic geophysicist. There is some argument for other techniques being tested more often, hence the above descriptions. This review article aims to reflect a range of current practices so a selection of articles is reviewed here. Prior to 1992, GPR was used widely in crime scene and military operations (Gary Olhoeft, personal communication, 2003) but rarely documented except in general terms in newspaper articles, the exception being Bevan (1990). Strongman (1992) published a series of case studies from controlled environment burials (5-yearold bear carcasses) as well as actual crime scene profiles. Owsley (1995) evaluated GPR against other geophysical devices and concluded that a physical probe was still a better device for use in the detection of buried objects. Miller (1996) followed the Strongman (1992) approach, with an evaluation of test sites against actual case studies. The development of the science was thus at an impasse through the late 1990s, as new technology and the next generation of laptop computers were developed. A rush of papers in 2000 reflects these advances and their application to actual forensic cases (Nobes, 2000), historic mass burials (Davis et al., 2000; Field et al., 2001) and the experimental responses of buried corpses (Hammon et al., 2000). The development of other geophysical techniques (see above) has caused a re-evaluation of GPR in comparison with other devices (Buck, 2003). Many of the early problems with GPR have now been solved: the development of shielded radar antennae has made usage in forests and houses possible. Likewise, many studies now deploy two or more geophysical techniques along the same survey lines, specifically to overcome individual problems of acquisition in one or other method. A good example is France et al. (1992) conjunctive use of electromagnetic, resistivity, GPR and other surveys in defining burial sites. The range of antennae available $(25-1000 \mathrm{MHz})$ now allows investigation of large (kilometre-scale) to very small (centimetre-scale) buried or hidden non-metallic objects. Wet, clay-rich and saline (or other electrolyte-impregnated) ground still cause problems, where other geophysical devices are required. A huge growth area in forensic type GPR work has been in plastic landmine detection (Chen et al., 2001) with a range of commercial devices and services available.

\subsubsection{Forensic geomorphology}

Possibly the most fundamental and straightforward form of remote sensing is the least-well 
documented: landscape interpretation. This lack of documentation may be the result of the somewhat 'low-tech' nature of simply observing changes in the landscape such as ground irregularities above buried objects. It takes the confidence and experience of a forensic scientist such as Douglas Owsley (Owsley, 1995) to state clearly the fundamental observations on which he bases probing in the search for buried bodies. In summary, Owsley describes how simply observing dips, hummocks, vegetation and drainage changes in the ground, followed by using a physical probe in forensic investigation can avoid expensive, destructive and time-consuming excavation. Owsley also describes the advantages of the probe over cadaver dogs and geophysics in urban, rubbish-filled, wooded and underground areas. However, as Owsley quotes "That the searchers must be trained-that is, they must have substantial practice and experience to use a probe successfully and minimize invasiveness - is perhaps the chief disadvantage." This approach was pioneered by Imaizumi (1974) and was vindicated by Ellwood et al. (1994) in their search for the grave of the hanged Texas gunfighter, William Preston Longley, in which a combined study of vegetation, geomorphology, photographs and geophysics were combined to form a highly effective search. Geomorphology encompasses the study of soils as well as landforms although most forensic work on soils concentrates on their makeup and analysis as trace evidence (see below) as opposed to their distribution and disturbance as a primary method of crime detection and suspect location. An unusual application of glacial geomorphology is described by Klene et al. (2002), who consider the uses frozen ground has in preserving trace evidence: the preservation of bodies in ice (such as the famous "Man in the Ice" of Spindler, 1994, is reviewed below).

\subsubsection{Forensic remote sensing}

Brilis et al. (2000a,b) and Grip et al. (2000) give a comprehensive overview of aerial photography, satellite imagery and global positioning systems applications to forensic investigations. These include environmental forensic investigations such as the mapping of covert release of industrial waste and the non-intrusive examination of scenes of crime. The emission of gases into the atmosphere may be detected by collection or by remote sensing methods (Ruffell, 2002). In many serious crimes a standard first approach is infrared and ultra-violet photography of the scene in order to detect ground disturbance and tyre travel positions. Other common forensic remote sensing applications include the monitoring of water currents in order to predict where bodies, toxic waste or munitions may be washed ashore (Hardisty, 2003).

\subsubsection{Geographic information systems}

Geographic Information Systems (GIS) have found most use in criminology in the prediction of crime and thus the targeting of police resources to certain geographic areas (Hirschfield and Bowers, 2001). The National Institute of Justice in the United States of America hosts the Crime Mapping Research Centre (www.ojp.usdoj.gov/cmrc) who give excellent examples of both the computer programmes available for the spatial analysis of criminal behaviour (e.g. CrimeStat), as well as case studies. The latter include the areal distribution of gun crimes in Pittsburgh and Texas, the likely locations of drug dealing in parts of Arizona and Florida and the predicted urban locations of crimes against women. Probably the most famous effective use of a GIS type approach to a forensic study is the work of the Victorian physician John Snow, who identified how cholera was spread by studying its geographic distribution, tracing the disease back to a seaman who travelled home to London from the far east, carrying the disease (Snow, 1855). The tracing of DNA from a suspect back to his or her home region or genetic roots now uses a GIS based approach (Zhivotovsky et al., 2001). GIS has been proven in court many times: Brodsky (2002) demonstrated how a fraudulent claim for loss of income from retail stores could be checked using the geographically spread income over a wide area using GIS. A GIS based approach to mapping crime scenes is now becoming commonplace (http://www.mywisecounty. com/news/100402-1.htm).

\subsubsection{A critical examination of the role geophysics and remote sensing plays in forensic investigations}

An interesting overview of the non-intrusive methods of crime detection and monitoring is given by Rinehart (2003). Rinehart (2003) does not detail electrical methods, reflecting their currently limited 
use in forensic geophysics. This is unfortunate as both resistivity (for mapping) and electrical tomography (for determining the depth geometry of disturbed materials) are useful techniques, deployed by many commercial companies and consultants but rarely published upon. Rinehart (2003) suggests that the magnetometer has some advantages in operation over snow and water. GPR also operates in these conditions, but not in marine environments. Rinehart (2003) states that GPR requires a relatively smooth surface, which is only true for rigid antennae (some are now flexible) and for minimising air-wave signals. Aerial and satellite photographs, metal detectors (for finding spent ordnance), cadaver dogs and the metal probe are considered powerful reconnaissance and investigative techniques. Rinehart (2003) suggests that the availability of aerial photographs is limited, when in reality aerial photographs are often the first, most common and widely accessed material in forensic geoscience: the problem may well be that such material are not commonly available to the independent scientist as opposed to the police or government. Rinehart also states that use of GPR and magnetometer is more theoretical than practical. Publications on magnetometer surveys in forensic work are indeed limited. GPR however is documented widely (see above) and is used very frequently at crime scenes worldwide.

\subsubsection{Forensic anthropology}

Many of the macro- and micro-scale case studies cited here are used during archaeological investigations, some of which become or are aimed at criminal investigation. In this way, much with forensic biology (below), there is enough literature on forensic archaeology to warrant a separate review paper to this one. However, one area that combines archaeological with other geoscience disciplines (geophysics, geomorphology) is the study of buried or hidden animal and human (anthropology) remains. Animal remains are studied during criminal investigations, such as the theft and killing of valuable livestock or zoo animals (see for instance the events leading to the Irish Republican Army killing of the Aga Khan's racehorse Shergar-http:/www.buzzle. com/editorials/3-12-2004-51611.asp), the illegal disposal of diseased animals and the need to differentiate human from animal remains. However, the majority of criminal investigations are concerned with human remains: this topic is at the core of the current interest in all things "forensic" in the media. This is largely because the discovery of human remains are still the most obvious application of forensic science, where the 'when and how' questions are asked. The age of inhumations, and how death occurred, through study of bone taphonomy, rates of tissue decay, associated geochemical changes to the sediment and insect activity are the main areas of current interest. Three semi-popular works demonstrate the conjunctive use of the geoscience techniques reviewed here with anthropology. Spindler (1994) provides a clear and precise account of the Neolithic "Man in the Ice", found at the Austrian-Italian border in the Alps. His book documents both the mistakes made in recovery, from which many forensic investigators could learn, as well as the details of all the materials discovered. Benedict (2003) documents the life and work of the great Smithsonian anthropologist Douglas Owsley, whose work on using a ground probe and associated observations of ground disturbance has already been cited here. Finally, Bass and Jefferson (2003) document the life and work of Bill Bass, centering on his gradual and tireless building of the "Body Farm" where corpses are experimentally buried, hidden or exposed and allowed to decay. Just as Spindler and Benedict (after Owsley: op cit.) are informative regarding search and recovery procedures, Bass and Jefferson's book (2003) is an excellent (albeit gruesome) guide for the experimental geoscientist.

\subsubsection{Forensic seismology}

The term 'forensic' is often used by those wishing to convey a detailed investigation as opposed to a criminological one. Forensic seismology is included in this section on geophysics and remote sensing as the technique includes aspects of each. The development of forensic seismology was primarily for remote monitoring of underground nuclear testing by China, the former Soviet Union and the United States, by each country, respectively (Zucca, 2003). Seismic monitoring has also been used in the identification and characterisation of other seismic events (Koper, 2003). These include two very important events where a remote observation through seismology was critical in understanding what had 
occurred. (1) The 7 August 1998 Truck-bombing of the US Embassy in Nairobi, Kenya occurred when terrorists exploded truck bombs nearly simultaneously at American embassies in Nairobi, Kenya and Dar es Salaam, Tanzania. In both cases the blasts were large enough that irreparable damage was done to both buildings. The Nairobi attack was recorded by a three-component, broadband seismometer, analysis of which allows estimate of the precise origin time of the explosion and the amount of blast energy partitioned into seismic ground motion (Koper, 2003). (2) The Sinking of the Russian Submarine Kursk on 10 August 2000 was detected by seismic networks in the Baltic area as two events. The first event was smaller than the second event. The Kursk data proved that there was no collision or impact. Air seismology will, in the future, be critical in assessing the type and location of explosions, large weapons discharge and accidents.

\subsection{The small scale}

At the microscopic level, forensic analysis has tended to concentrate on materials of centimetre to sub-millimetre scale that can be used in linking scenes of crime to suspects. An excellent guide to the range of applications that microscopy has in forensic geochemistry can be obtained in Palenik (2000; and related chapters). Established methods used in matching soil, building products and rock debris from scenes of crime to suspect's shoes, clothing, vehicles and houses include colour (Marumo and Sugita, 1996; Janssen et al., 1983) and visual inspection of recovered debris. The use of the petrographic microscope significantly advanced geological applications to forensic science (Murray and Tedrow, 1991). Since the early 1990s there has been a gradual increase in the range of analyses available to those matching scene of crime to suspects; particle-size analysis; (Marumo and Sugita, 2001; Blott et al., 2003); scanning electron microscopy (Righi and Elsass, 1996; Goggin et al., 2003; Pirrie et al., 2003) and palynology (Bock and Norris, 1997; Horrocks et al., 1999) have all been used with varying success. The conjunctive approach is perhaps the best, with mineralogy and palynology being used together and showing the best potential (Brown et al., 2002). Space precludes consideration of the aspects of forensic biology (diatoms, Juggins and Cameron, 1999; palynomorphs, Horrocks et al., 1999; Wiltshire, 2003; foraminifera, testate amoebae, Chardez and Lambert, 1985; insects, Saferstein, 2001, 2002; Wiltshire, 2001) that may be used in forensic investigations. A review paper on forensic non-human biology is probably needed.

\subsection{Forensic mineralogy}

The study of mineralogy for forensic examinations tends to fall into two groups: soil analysis and unusual materials such as glass, rock fragments and powders, processed minerals for foodstuffs, manufacturing, cosmetics and pharmaceuticals. The analysis of soils is one of the earliest applications of geology to forensic cases (see the synopses of Popp, Gross and Conan Doyle, above). Murray and Tedrow (1991) give an invaluable account of the role mineralogy has in the sequence of analytical procedures that soil or minerals may be investigated by. The INTERPOL website (INTERPOL, 2001), Houck (2001) and Junger (1996) give overviews of current practice. The above authors follow Palenik's procedure in terms of the sequence of soil analysis, from analysis of colour, organic content, coarse and fine fraction microscopy, heavy mineral and light mineral identification and then specialist studies. It tends to be the specialist studies that cause debate in literature, with methods such as the density column becoming popular, then falling from favour and recently resurfacing as a possibly viable method (Petraco and Kubic, 2000). Somewhat behind the scenes, and concurrent with the rise and fall of these sophisticated techniques, over the past 30 years (since Murray and Tedrow, 1975), the light polarizing microscope has remained a reliable method of comparing rock, sediment and soil for criminal investigation (Murray, 2004). X-ray powder diffraction remains the best available technique for the identification of minerals in fine-grained materials such as soils, rock dust, building debris and rocks (Srodon et al., 2001) XRD identifies primary minerals (as opposed to chemicals or secondary chemicals) of a sample size that is often equivalent to typical recoveries from SOC and suspects (Righi and Elsass, 1996). The QXRD technique (www. 
forensicgeology.net) can now be deployed conjunctively with traditional mineral identification to give both statistical reliability (Ruffell and Wiltshire, in press) in mineralogically similar soils, rocks, etc., as well as the possible detection of a unique mineral as a unique comparator. Nonetheless, crude comparisons of soil makeup can prove a problem in forensic science (Junger, 1996), given the wide variation over a small (centimetre) distance.

\subsection{Forensic geochemistry}

The application of geochemical techniques to forensic science is where the distinction between geoscience and the range of other scientific investigative techniques breaks down. Methods used commonly in determining the composition of rocks, soils, minerals, fossils and archaeological human remains are also used in assessing the composition of human hair, bullets, explosives, narcotics and forged materials (Cave and Wragg, 1997). The Geoscience aspect of the forensic investigation again comes back to the use of geochemistry in assessing the usefulness of natural materials to criminal investigations (Cox et al., 2000). Various geochemical methods are used in the dating of materials. These include radiocarbon dating (e.g. dating human remains to determine whether a crime is recent or not: Wienker et al., 1990). Tree-ring dating (or dendrochronology) may be used where wood has been used as a weapon, in burials, as a covert storage medium or in assessing possible fake materials (e.g. Topham and McCormick, 2000). The problem of dating human remains that are less than 50 years old is critical in forensic archaeology. Recent advances have utilised the man-made isotope content as a method of determining maximum age, the differing nuclear weapons detonated over the past 57 years have produced individual isotope profiles, creating a possible dating method (Black, 2003). The microscopic chemistry of materials can now be determined using some form of mass spectrometry, usually in the form of laser that ablates a surface and the generated gas is analysed (McVicar and Graves, 1997; Pirrie et al., 2003). This allows statistical comparison of elemental values as opposed to visual (textural) comparison. A well-documented application of geochemistry to criminal investigation is the geochem- ical makeup of papers and inks used in forged documents and bank notes. Perhaps the most famous geochemical investigation of forgery is Walter McCrone's (see above) analysis of the Vinland Map, which purported to show that the Vikings visited America before Columbus in 1492. Beta radiography showed the paper was made around 1450 , but McCrone's analysis of the ink showed elements that were not used before 1930, suggesting faked writing on an ancient paper. In a second case, a catastrophic fire at the Royal Bank of Scotland in Edinburgh apparently destroyed all the stored bank notes, as only paper ash was recovered. The ash from burnt, used bank notes was accessed from the mint (who destroy old notes) and subjected to X-ray fluorescence analysis. The ash from the bank fire was analysed by the same means, and the two did not compare. The most likely source of burnt paper, newspaper, was also then analysed and the likely source of the fake burnt notes discovered to be the Daily Mail, a commonly available English newspaper! Isotopes of various elements are now used to compare explosives, drugs and human bones: the Nigerian origin of 'Adam' - the torso in the Thames (Hunter, 2003) was elucidated by Professor Kenneth Pye using strontium isotopes from the corpse.

\subsection{Extraterrestrial forensic geoscience}

Spacecraft orbiting the Earth may collide with natural or anthropogenic (space junk) particles. Differentiating these objects is important, both in devising protective coatings for spacecraft as well as pursuing potential litigants. Graham et al. (2003) discuss precisely this problem and show the classic forensic microscopic comparison of impact, suspect object and associated chemical residues. The increase in orbiting craft and materials can only result in further studies of this sort.

\section{Conclusions}

The approach of the forensic scientist is subtly different to that of other research-led workers: the conclusion for the former may be a court of law and for the latter, a journal publication. The conduct, 
presentation and problems in misinterpretation are very different in each. The role of the forensic scientist is often very focussed: determining a specific answer to a question such as: can a material on a suspect be linked to a scene of crime? This would not be a common question to ask in a research journal, but the method(s) of obtaining the answer would be. Thus we believe that both sides (forensic [or criminalistic] and non-forensic) of the scientific community have a great deal to learn from each other. As pure research-based scientists until a few years ago, we have learnt more from work in the forensic sector than we could have done in nonapplied training. Hence our desire to inform the readers of Earth Science Reviews (rather than a forensic-based journal) that new approaches, materials and methods to our problems are in the public domain that we may all benefit from. Likewise, physical scientists may have much to offer domestic and international criminal investigators. Hence, 100 years after Georg Popp first matched a suspect's shoes to a scene of crime, we hope it is fitting to advertise the compendia of Saferstein $(2001,2002)$, Pye and Croft (in press) and Murray (2004) in a journal article such as this. This article is a mere snapshot of all the available information. It is highly selective, with accessible articles and websites favoured in order to begin to get non-forensic scientists in dialogue with non-geoscience trained forensic scientists. The future, as one can see from the above macro-scale (France et al., 1992; Field et al., 2001) and micro-scale (Croft and Pye, 2004) studies will be in the statistical testing of multiple analytical methods.

\section{Acknowledgements}

The desire to write this came from discussions with Steve Bell, Mark Cooper, Clark Davenport, Tom Davitt, Colin Dempsey, Jane Holmes, Harry Jol, Bob Kalin, Will Kerr, Brian Lavery, Roy McComb, Keith McCoubrey, Steven McKendry, Jim McQuillan, Wolfram Meier-Augenstein, Ian Meighan, Jennifer Miller, Paul Moore, Eileen Murphy, Gary Olhoeft, Duncan Pirrie, Ken Pye, Rick Schulting, Jonathan Smith, Jim Spears, Andrew Tyler, Pat Wiltshire. Thanks to Dave Nobes, Dave
Favis-Mortlock, Gerry Friedman and Graeme Swindles for their advice.

\section{References}

Andrews, S., 2002. Fault Line. St. Martin's Minotaur, New York. 307 pp.

Bass, W.M., Birkby, W.H., 1978. Exhumation: the method could make the difference. FBI Law Enforcement Bulletin 47, 6-11.

Bass, W.M., Jefferson, J., 2003. Death's Acre. TimeWarner Books, London. 299 pp.

Benedict, J., 2003. No Bone Unturned. HarperCollins, New York. 304 pp.

Bevan, B.W., 1990. The search for graves. Geophysics 56, $1310-1319$.

Black, S., 2003. Accurate determination of the post-mortem interval in human skeletal remains. In: Pye, K., Croft, D. (Eds.), Forensic Geoscience: Principles, Techniques and Applications. Conference Abstracts, Geological Society of London, 3-4 March 2003, p. 13.

Blott, S.J., Croft, D.J., Pye, K., Saye, S.E., Wilson, H.E., 2003. Particle size determination of soils for forensic purposes using laser diffraction. In: Pye, K., Croft, D. (Eds.), Forensic Geoscience: Principles, Techniques and Applications. Conference Abstracts, Geological Society of London, 3-4 March 2003, p. 14.

Bock, J.H., Norris, D.O., 1997. Forensic botany: an under-utilized resouce. Journal of Forensic Sciences 42, 364-367.

Brilis, G.M., Gerlach, C.L., van Waasbergen, R.J., 2000a. Remote sensing tools assist in environmental forensics: Part I. Digital tools - traditional methods. Environmental Forensics $1,63-67$.

Brilis, G.M., van Waasbergen, R.J., Stokely, P.M., Gerlach, C.L., 2000b. Remote sensing tools assist in environmental forensics: Part II. Digital tools. Environmental Forensics 1, 1-7.

British Broadcasting Centre, 2003. Silent witness. http://www. bbc.co.uk/drama/crime/silentwitness (accessed 23/6/2003).

Brodsky, H., 2002. GIS goes to court making a case for forensic mapping. Geo Info Systems 12 (3), 48.

Brown, A.G., Smith, A., Elmhurst, O., 2002. The combined use of pollen and soil analyses in a search and subsequent murder investigation. Journal of Forensic Sciences 47, 614-618.

Buck, S.C., 2003. Searching for graves using geophysical technology: field tests with ground penetrating radar, magnetometry, and electrical resistivity. Journal of Forensic Sciences 48, 5-11.

Cave, M.R., Wragg, J., 1997. Measurement of trace element distributions in soils and sediments using sequential leach data and a non-specific extraction system with chemometric data processing. Analyst 122, 1211-1221.

Chamakura, R.P., 2001. http://www.forensicpage.com/new05.htm (accessed 30/6/2004).

Chambers English Dictionary, 2003. Pub. Chambers, Edinburgh. $1856 \mathrm{pp}$.

Chardez, D., Lambert, J., 1985. Protozaires cilies et thanatologie. Forensic Science International 28, 83-101. 
Cheetham, P., 2003. A practical and effective, high-resolution, symmetrical response and reduced near-surface noise multiple potential electrode resistivity array configuration for the detection of clandestine graves. In: Pye, K., Croft, D. (Eds.), Forensic Geoscience: Principles, Techniques and Applications. Conference Abstracts, Geological Society of London, 3-4 March 2003, p. 17.

Chen, C.-C., K., Rama, R., Lee, R., 2001. A tapered-permittivity rod antenna for ground penetrating radar applications. Journal of Applied Geophysics 47, 309-316.

Chisum, W., Turvey, B., 2000. Evidence dynamics: locard's exchange principle and crime reconstruction. Journal of Behavioral Profiling 1, 1-15.

Columbia Broadcasting Service, 2003. Crime scene investigators. http://www.cbs.com/primetime/csi/main.shtml (accessed 23/6/2004).

Cox, R.J., Peterson, H.L., Young, J., Cusik, C., Espinoza, E.O., 2000. The forensic analysis of soil organic by FTIR. Forensic Science International 108, 107-116.

Crelling, J., 1998. http://mccoy.lib.siu.edu/projects/geology/ geol483/int483_b.html (accessed 30/6/2004).

Croft, D.J., Pye, K., 2004. Multi-technique comparison of source and primary transfer soil samples: an experimental investigation. Science and Justice 44, 21-28.

Davenport, G.C., 2001a. Remote sensing applications in forensic investigations historical archaeology 351 .

Davenport, G.C., 2001b. http://www.technos-inc.com/Surface. html\#I22 (accessed 6/6/2004).

Davis, J.L., Heginbottom, J.A., Annan, A.P., Daniels, R.S., Berdal, B.P., Bergan, T., Duncan, K.E., Lewin, P.K., Oxford, J.S., Roberts, N., Skehel, J.J., Smith, C.R., 2000. Ground penetrating radar surveys to locate 1918 Spanish Flu victims in Permafrost. Journal of Forensic Sciences 45, 68-76.

Ellwood, B.B., Owsley, D.W., Ellwood, S.H., Mercado-Allinger, P.A., 1994. Search for the grave of the hanged Texas gunfighter, William Preston Longley. Historical Archaeology 28, 94-112.

Field, G., Leonard, G., Nobes, D.C., 2001. Where is Percy Rutherford's grave? In: Jones, M., Sheppard, P. (Eds.), Australasian Connections and New Directions: Proceedings of the 7th Australasian Archaeometry Conference, Research in Anthropology and Linguistics, vol. 5. University of Auckland, Auckland, pp. 131-147.

France, D.L., Griffin, T.J., Swanburg, J.G., Lindemann, J.W., Davenport, G.C., Trammell, V., Armbrust, C.T., Kondratieff, B., Nelson, A., Castellano, K., Hopkins, D., 1992. A multidisciplinary approach to the detection of clandestine graves. Journal of Forensic Sciences 37, 1445-1458.

Goggin, P., Faulkner, M., Pye, K., Croft, D., Blott, S.J., 2003. Morphological and chemical analysis of particulates in forensic samples using a variable pressure scaning electron microscope: the Hitachi S-3000N. In: Pye, K., Croft, D. (Eds.), Forensic Geoscience: Principles, Techniques and Applications. Conference Abstracts, Geological Society of London, 3-4 March 2003, p. 26.

Graham, G.A., Kearsley, A.T., Wright, I.P., Grady, M.M., 2003. Forensic geoscience analysis of spacecraft surfaces: identifying who or what is responsible for damage to satellites. In: Pye, K., Croft, D. (Eds.), Forensic Geoscience: Principles, Techniques and Applications. Conference Abstracts, Geological Society of London, 3-4 March 2003, p. 27.

Grip, W.M., Grip, R.W., Morrison, R., 2000. Application of aerial photography in environmental forensic investigations. Environmental Forensics 1, 121-129.

Hammon, W.S., McMechan, G.A., Zeng, X.X., 2000. Forensic GPR: finite-difference simulations of responses from buried human remains. Journal of Applied Geophysics 45, $171-186$.

Hardisty, J., 2003. Hydrodynamic modelling as investigative and evidential tools in murder enquiries: examples from the humber and thames. In: Pye, K., Croft, D. (Eds.), Forensic Geoscience: Principles, Techniques and Applications. Conference Abstracts, Geological Society of London, 3-4 March 2003, p. 29.

Hirschfield, A., Bowers, K. (Eds.), 2001. Mapping and Analysing Crime Data: Lessons from Research and Practice. Taylor and Francis, London. 312 pp.

Holt, C., 2004. Forensic science resources on the internet, http:// www.istl.org/03-spring/internet.html (accessed 30/6/2004).

Horrocks, M., Coulson, S.A., Walsh, K.A.J., 1999. Forensic palynology: variation in the pollen content of soil on shoes and in shoeprints in soil. Journal of Forensic Sciences 44, 119-122.

Houck, M.M. (Ed.), 2003. Mute Witnesses. Academic Press, London. 188 pp.

Hunter, P., 2003. Adam: a 21st century murder mystery. The Scientist 17 (13), 30 (http://www.the-scientist.com/yr2003/jun/ research2_030630.html: accessed 17th July, 2004).

Imaizumi, M., 1974. Locating buried bodies. FBI Law Enforcement Bulletin 43, 2-5.

INTERPOL, 2001. Forensic Science Symposium, Lyon, France, October 16-19, http://www.interpol.int/Public/Forensic/IFSS/ meeting13/Reviews/Soil.pdf (accessed 12/1/2004).

Janssen, D.W., Ruhf, W.A., Prichard, W.W., 1983. The use of clay for soil color comparisons. Journal of Forensic Sciences 28, $773-776$.

Juggins, S., Cameron, N., 1999. Diatoms and archaeology. In: Stoermer, E.F. (Ed.), The Diatoms; Applications for the Environmental and Earth Sciences. Cambridge University Press, Cambridge, pp. 389-401.

Junger, E.P., 1996. Assessing the unique characteristics of closeproximity soil samples: just how useful is soil evidence? Journal of Forensic Sciences 41, 27-34.

Klene, A.E., Nelson, F.E., Rogers, D., Shiklomanov, N.I., 2002. Permafrost science and secondary education: direct involvement of teachers and students if field research. Geomorphology 47, $275-287$.

Koper, K., 2003. http://www.geo.arizona.edu/researchers/ kkoper_ftp/for_cases.html (accessed 30/6/2004).

Lewis, P., 2002. Walter McCrone, debunker of legends, dies aged 82. http://membership.acs.org/C/Chicago/mccrone.html (accessed 1/2/2004).

Marumo, Y., Sugita, R., 1996. Validity of color examination for forensic soil identification. Forensic Science International 83, 201-210. 
Marumo, Y., Sugita, R., 2001. Screening of soil evidence by a combination of simple techniques: validity of particle size distribution. Forensic Science International 122, 155-158.

McVicar, M.J., Graves, W.J., 1997. The forensic comparison of soils by automated scanning electron microscopy. Canadian Society of Forensic Science Journal 30, 241-261.

Miller, P.S., 1996. Disturbances in the soil: finding buried bodies and other evidence using ground penetrating radar. Journal of Forensic Sciences 41, 648-652.

Murray, R., Tedrow, J.C.F., 1975. Forensic Geology: Earth Sciences and Criminal Investigation (republished 1986). Rutgers University Press, New York. 240 pp.

Murray, R.C., 2004. Evidence from the Earth: Forensic Geology and Criminal Investigation. Mountain Press Publishing, Missoula, MT. 227 pp.

Murray, R.C., Tedrow, J.C.F., 1991. Forensic Geology (may be cited as 1992). Prentice Hall, Englewood Cliffs, NJ. 240 pp.

Nielsen, B., 2003. Patrcia cornwell bibliography, http://www. 246.dk/cornwell.html (accessed 30/6/2004).

Nobes, D.C., 1999. Geophysical surveys of burial sites: a case study of the Oaro urupa. Geophysics 64, 357-367.

Nobes, D.C., 2000. The search for "yvonne": a case example of the delineation of a grave using near-surface geophysical methods. Journal of Forensic Sciences 45, 715-721.

Odell, R., 1982. Police organisation. In: Deutch, Y. (Ed.), Science Against Crime. Marshall Cavendish House, London, pp. $164-179$.

Owsley, D.W., 1995. Techniques for locating burials, with emphasis on the probe. Journal of Forensic Sciences 40, 735-740.

Palenik, S.J., 2000. Microscopy. In: Siegel, J., Knupfer, G., Saukko, P. (Eds.), Encyclopedia of Forensic Science. Academic Press, New York.

Petraco, N., Kubic, T., 2000. A density gradient technique for use in forensic soil analysis. Forensic Science International 4, $872-873$

Pirrie, D., Butcher, A.R., Gottlieb, P., Power, M.R., 2003. QemSCAN - a fully automated quantitative SEM-based mineral analysis system. In: Pye, K., Croft, D. (Eds.), Forensic Geoscience: Principles. Techniques and Applications. Conference Abstracts, Geological Society of London, 3-4 March 2003, p. 38 .

Pozdnyakova, L., 2003. http://www.landviser.com/forensic.htm (accessed 20/6/2004).

Pye, K., Croft, D. (Eds.), 2004. Forensic Geoscience: Principles, Techniques and Applications, Special Publication Geological Society of London. 232, 313 pp.

Righi, D., Elsass, F., 1996. Characterization of soil clay minerals: decomposition of X-ray diffraction diagrams and highresolution electron microscopy. Clays and Clay Minerals 44, $791-800$.
Rinehart, D., 2003. Excavations of skeletal remains from an anthropological point of view. http://www.crime-scene-investigator.net/ excavation.html (accessed 20/6/2004).

Ruffell, A., 2002. Remote detection and identification of organic remains: an assessment of archeological potential. Archaeological Prospection 9, 115-122.

Ruffell, A., Wiltshire, P., 2004. Conjunctive use of quantitative and qualitative X-ray diffraction analysis of soils and rocks for forensic analysis. Journal of Forensic Sciences 49 (in press).

Saferstein, R.E., 2001. Criminalistics: An Introduction to Forensic Science, 7th ed. Prentice-Hall International, New Jersey, 576 pp.

Saferstein, R.E., 2002. Forensic Science Handbook. Prentice Hall, New Jersey, 784 pp.

Snow, J., 1855. On the Mode of Communication of Cholera. John Churchill, London, 38 pp.

Spindler, K., 1994. The Man in the Ice. Weidenfeld and Nicolson, London, $305 \mathrm{pp}$.

Srodon, J., Drits, V.A., McCarty, D.K., Hsieh, J.C.C., Eberl, D.D., 2001. Quantitative X-ray diffraction analysis of clay-bearing rocks from random preparations. Clays and Clay Minerals 49, $514-528$.

Strongman, K.B., 1992. Forensic applications of ground penetrating radar. In: Pilon, J. (Ed.), Ground Penetrating Radar, PaperGeological Survey of Canada, vol. 90-4, pp. 203-211.

Topham, J., McCormick, D., 2000. A dendrochronological investigation of stringed instruments of the cremonese school (1666-1757) including "the messiah" violin attributed to Antonio Stradivari. Journal of Archaeological Science 27 (No. 3), $183-192$.

van Schoor, M., 2002. Detection of sinkholes using 2D electrical resistivity imaging. Journal of Applied Geophysics 50, 393-399.

Wienker, C.W., Wood, J.E., Diggs, C.A., 1990. Independent instances of "souvenir" Asian skulls from the Tampa Bay area. Journal of Forensic Sciences 35, 637-643.

Wiltshire, P.E.J., 2001. Environmental profiling and forensic palynology, http://www.bahid.org/docs/NCF_Env\%20Prof.pdf (accessed 17th July 2004).

Wiltshire, P.E.J., 2003. Pollen and related botanical evidence-its recent contribution to forensic investigations. In: Pye, K., Croft, D. (Eds.), Forensic Geoscience: Principles, Techniques and Applications. Conference Abstracts, Geological Society of London 3-4 March 2003, p. 51.

Zhivotovsky, L.A., Ahmed, S., Wang, W., Bittles, A.H., 2001. The forensic DNA implications of genetic differentiation between endogamous communities. Forensic Science International 119, $269-272$.

Zucca, 2003. http://www.1lnl.gov/str/Zucca.html (accessed $30 / 6 / 2004)$. 